\title{
Sosialisasi Resiko Non Klinis Pernikahan Usia Anak di SMAN I Gerung
}

\author{
Eneng Garnika*, Dewi Rayani, Lu'luin Najwa, Diah Lukitasari \\ Program Studi Bimbingan dan Konseling, Administrasi Pendidikan \\ FIPP Universitas Pendidikan Mandalika \\ *Corresponding Author: enenggarnika@ikipmataram.ac.id
}

\begin{abstract}
This community service activity aims to provide knowledge in child marriage which can cause bad risks, so it is necessary to do prevention by delaying the age of marriage, continuing studies and planning life to be able to carry it out better. Given the appeal from the government not to carry out activities that involve many people, this service program is carried out through socialization in limited classes to be able to maintain the Health protocol with a number of participants less than 20 pesetas. The steps in the implementation of this service include: (1) Providing gradual education to students about the nonclinical risks of child marriage and its prevention; Non-clinical risks of child marriage; planning for the future and further studies, and the importance of education to continue a better life. (2) Conduct a question and answer session at the end of the delivery of socialization materials. (3) Evaluation of child marriage risk socialization program activities and program sustainability plans. The result of this community service activity is that students understand the non-clinical risks of child marriage and can plan for the future, by continuing their studies or by doing entrepreneurship.
\end{abstract}

\begin{abstract}
Abstrak: Kegiatan pengabdian kepada masyarakat ini bertujuan untuk memberikan pengetahuan dalam pernikahan usia anak yang dapat menimbulkan resiko-resiko buruk, sehingga perlu dilakukan pencegahan dengan menunda usia nikah, melanjutkan studi dan merencanakan kehidupan untuk dapat melangsungkannya dengan lebih baik. Mengingat himbauan dari pemerintah untuk tidak melakukan kegiatan yang melibatkan banyak orang, maka program pengabdian ini dilakukan melalui sosialisasi dalam kelas terbatas untuk dapat tetap menjaga protokol Kesehatan dengan jumlah peserta kurang dari 20 peseta. Langkah-langkah dalam pelaksanaan pengabdian ini antara lain: (1) Memberikan penyuluhan secara bertahap kepada siswa-siswi tentang resikoresiko non klinis dari pernikahan usia anak dan pencegahannya; Resiko non klinis pernikahan usia anak; merencanakan masa depan dan lanjut studi, dan Pentingnya Pendidikan untuk melanjutkan kehidupan yang lebih baik. (2) Melakukan sesi tanya jawab setiap akhir penyampaian materi sosialisasi. (3) Evaluasi kegiatan program sosialisasi resiko pernikahan usia anak dan rencana keberlanjutan program. Hasil kegiatan pengabdian kepada masyarakat ini adalah siswa-siswi memahami resiko non klinis dari pernikahan usia anak dan dapat merencanakan masa depan, dengan cara melanjutkan studi maupun dengan berwirausaha.
\end{abstract}

\section{Article History:}

Received: 22-03-2021

Reviewed: 07-04-2021

Accepted: 09-04-2021

Published: 05-05-2021

Key Words:

Socialization, Child

Marriage,

Nonclinical Risk.

\section{Sejarah Artikel:}

Diterima: 22-03-2021

Direview: 07-04-2021

Disetujui: 09-04-2021

Diterbitkan: 05-05-2021

\section{Kata Kunci:}

Sosialisasi, Resiko Non Klinis, Pernikahan Usia Anak.

How to Cite: Garnika, E., Rayani, D., Najwa, L., \& Lukitasari, D. (2021). Sosialisasi Resiko Non Klinis Pernikahan Usia Anak di SMAN I Gerung. Jurnal Pengabdian UNDIKMA, 2(1), 98-103. doi:https://doi.org/10.33394/jpu.v2i1.3585

doi:https://doi.org/10.33394/jpu.v2i1.3585

This is an open-access article under the CC-BY-SA License.

\section{Pendahuluan}

Menurut United Nations Development Economic and Social Affairs (UNDESA 2010 dalam Kemkes 2015), Indonesia merupakan negara ke-37 dengan prosentase pernikahan usia 
muda yang tinggi dan merupakan tertinggi kedua di ASEAN setelah kamboja. Data Riset Kesehatan Dasar (Riskesdas) tahun 2013 menunjukkan bahwa, proses pertumbuhan masih berlangsung sampai dengan usia 18 tahun, umur 6-12 tahun perlu mendapatkan perhatian khusus untuk tidak menikah (Noor Syahadatina, M., dkk : 2018).

Pernikahan usia anak merupakan pernikahan yang terjadi secara formal atau tidak formal yang dilakukan di bawah usia 18 tahun (UNICEF, 2014). Sedangkan pernikahan usia anak menurut BKKBN merupakan pernikahan yang dilakukan remaja di bawah usia minimum. Usia minimum yang dianggap sudah cukup matang untuk menikah adalah perempuan usia 21 tahun dan laki-laki usia 25 tahun. Pada usia tersebut dianggap usia yang telah matang secara psikologis, pendidikan, pekerjaan, dan kemampuan fisik khususnya bagi perempuan untuk hamil dan melahirkan (BKKBN 2010).

Semenjak adanya corona virus disease-19 (Covid-19) yang menyebabkan permasalahan di berbagai sektor salah satunya yaitu sektor pendidikan. Kebijakan pemerintah untuk meliburkan sekolah dan menerapkan sekolah dalam jaringan (daring) menimbulkan banyak permasalahan, salah satunya meningkatnya jumlah pernikahan usia anak. Kasus pernikahan dini di Lombok Barat mencapai 480 di masa pandemi. Sekretaris Dinas Pemberdayaan Perempuan, Perlindungan Anak, Pengendalian Penduduk dan Keluarga Berencana, Erny Suryana mengatakan tahun 2020 ada kasus 18 persen pernikahan dini (usia di bawah 20 tahun) (SuaraNTB, 10 Februari 2020). Usia harus menjadi pertimbangan bagi masyarakat dalam melangsungkan pernikahan, ini terkait dengan kedewasaan fisik dan mental.

Salah satu faktor yang menyebabkan pernikahan usia anak adalah pendidikan yang rendah. Pendidikan yang rendah sangat mempengaruhi pola pemikiran suatu masyarakat, baik dari pendidikan orangtua maupun si anak sendiri. Tingkat pendidikan mempengaruhi tingkat kematangan kepribadian seseorang, dengan pendidikan mereka akan lebih menyaring dan menerima suatu perubahan yang baik, dan merespon lingkungan yang dapat mempengaruhi kemampuan berfikir mereka (Muntamanah, dkk, 2019).

Pernikahan usia anak menimbulkan resiko-resiko baik secara klinis maupun non klinis dalam jangka pendek maupun jangka panjang. Pencegahan pernikahan usia anak menjadi sangat penting diperhatikan. Pencegahan pernikahan usia anak perlu mendapat perhatian. Perhatian yang dapat diberikan salah satunya melalui berbagai layanan informasi dan sosialisasi. Target dan luaran yang diharapkan dari kegiatan pengabdian kepada masyarakat ini yakni, 1) Sosialisasi ini bertujuan untuk memberikan pengetahuan kepada anak usia remaja (SMAN 1 Gerung) mengenai resiko non klinis yang dapat ditimbulkan oleh pernikahan usia dini; 2) Selain memberikan pemahaman tentang berbagai resiko non klinis yang ditimbulkan, kegiatan ini juga bertujuan untuk memberikan layanan informasi bagi siswa SMAN 1 Gerung untuk merencanakan studi lanjut. Layanan studi lanjut merupakan suatu layanan yang memberikan informasi kepada siswa Sekolah Menengah Atas untuk dapat menentukan kemana arah siswa tersebut ketika selesai pada jenjang pendidikan yang sedang dijalani (Endriani, Ani., dkk. 2020; Suarti dkk, 2020).

\section{Metode Pengabdian}

Metode dalam pelaksanaan kegiatan pengabdian pada masyarakat ini adalah dalam bentuk sosialisasi/penyuluhan menggunakan sistem ceramah serta diskusi terbuka. Melalui metode ini, penyampaian materi dapat lebih mudah untuk disampaikan dan siswa dapat lebih leluasa berpartisipasi untuk bertanya tentang berbagai hal yang berhubungan dengan pernikahan usia anak dan berbagai resiko yang akan ditimbulkan. 
Pelaksanaan kegiatan pengabdian masyarakat ini dimulai dengan koordinasi bersama antara tim pengabdian (antara dosen) untuk menyiapkan berbagai kebutuhan dan mekanisme kegiatan pengabdian. Selanjutnya tim pengabdian melakukan komunikasi dan koordinasi dengan kepala sekolah dan guru di SMAN 1 Gerung, hal ini dilakukan untuk menyamakan persepsi terkait dengan teknis pelaksanaan kegiatan pengabdian. Koordinasi dilakukan dengan melakukan pertemuan di sekolah, dan sekaligus mengadakan diskusi dan observasi terkait dengan tempat, waktu, dan peserta kegiatan pengabdian. Mengingat himbauan dari pemerintah untuk tidak melakukan kegiatan yang melibatkan banyak orang, maka program pengabdian ini dilakukan pada siswa siswi kelas XII dengan jumlah peserta 40 siswa. Selanjutnya tim pengabdian mengembangkan berbagai materi yang akan disampaikan serta menjadi pedoman bagi peserta selama mengikuti kegiatan dan pengabdian. Tim pengabdian juga menyiapkan berbagai perlengkapan yang menunjang kegiatan antara lain; presensi, dokumentasi, dll.

Di akhir kegiatan peserta dan Tim melakukan refleksi hasil sosialisasi. Setelah semua kegiatan yang telah direncanakan terlaksana, ketua tim Pengabdian Masyarakat menutup program dan memberikan pesan kepada segenap peserta sosialisasi untuk menunda menikah pada usia anak, merencanakan masa depan, melanjutkan pendidikan untuk melanjutkan kehidupan yang lebih baik, merencanakan masa depan dengan lebih baik lagi serta selalu mengingat resiko-resiko menikah di usia anak. Diharapkan pada pengabdian masyarakat yang akan akan datang program ini dapat dilanjutkan lagi dengan bahasan yang lainnya.

\section{Hasil Pengabdian dan Pembahasan}

Hasil kegiatan pengadian ini mendapat respon yang sangat baik dan mendukung kegiatan ini untuk dilakukan karena dapat menjadi media bagi siswa untuk memahami resiko non klinis pernikahan usia anak, menentukan keputusan yang akan diambil berhubungan dengan cita-cita setelah menyelesaikan studi di SMA, memberikan solusi dalam mengatasi masalah studi lanjut. Materi-materi yang disampaikan oleh tim pengabdian disusun berdasarkan kebutuhan siswa yang sebelumnya telah didiskusikan pada tahap perencanaan bersama guru dan kepala sekolah.

Materi yang disajikan terkait dalam sosialisasi resiko-resiko non klinis pernikahan usia anak bagi siswa-siswi SMAN I Gerung antara lain berupa sosialisasi resiko-resiko non klinis pernikahan dini, bagaimana merencanakan masa depan dan melanjutkan studi, pentingnya pendidikan untuk melanjutkan kehidupan yang lebih baik lagi, menunda menikah di usia anak.

Materi yang disajikan oleh pengabdi dapat diterima, dicerna, dan dipahami peserta dengan baik. Pengabdi yang berperan sebagai instruktur dan tutor menjadikan sosialisasi ini menjadi lebih kondusif. Berdasarkan diskusi yang dilaksanakan setelah pemaparan materi, dapat dilihat bahwa para siswa siswi dapat memahami urgensi pencegahan pernikahan usia anak. Cara pencegahan mengetahui resiko-resiko buruk yang dapat ditimbulkan dari pernikahan usia anak, pentingnya Pendidikan dan melanjutkan studi, serta pentingnya merencanakan kehidupan untuk dapat melangsungkan kehidupan yang lebih baik lagi.

Tabel 1. Daftar Jenis Kegiatan, Materi dan Pemateri

\begin{tabular}{|l|l|}
\hline \multicolumn{1}{|c|}{ Pokok Bahasan (Materi) } & \multicolumn{1}{c|}{ Pemateri } \\
\hline 1) & $\begin{array}{l}\text { Pengantar dan Gambaran dasar tentang } \\
\text { pernikahan dini yang terjadi di Nusa } \\
\text { Tenggara Barat }\end{array}$ \\
\hline
\end{tabular}


2) Perkembangan remaja serta beberapa permasalahan yang biasa dihadapi oleh individu remaja

3) Gambaran problematika pernikahan usia anak

4) Resiko resiko klinis dan psikologis pernikahan usia anak

Dalam Mubasyaroh (2016), tedapat beberapa faktor bagaimana pernikahan dini ini dapat terjadi diantaranya adalah adanya faktor ekonomi, perjodohan, faktor kecelakaan (terjadi kehamilan di luar nikah), karena tradisi keluarga dan dan adanya faktor pendidikan. Berdasarkan faktor pendidikan disebutkan bahwa $70 \%$ pernikahan dini disebabkan oleh faktor pendidikan dengan penjelasan bahwa individu yang menikah dini disebabkan karena tingkat pendidikan yang rendah dan tidak melanjutkan pendidikan ke jenjang yang lebih tinggi (Pramana, 2012).

Dengan demikian, dalam sosialisasi ini para siswa dianjurkan untuk melakukan studi lanjut guna mencegah terjadinya pernikahan di usia dini mengingat siswa SMAN 1 Gerung masih tergolong dalam kategori remaja yang mana remaja merupakan masa transisi antara anak anak dan orang dewasa yang belum dapat mengambil keputusan dengan bijak. Sedangkan bahtera pernikahan mempertemukan dua individu yang berbeda, memiliki latar belakang berbeda, otak yang berbeda dan bahkan gender yang berbeda. Perbedaan ini tentunya akan banyak menimbulkan berbagai permasalahan yang harus dihadapi dan disikapi dengan kedewasaann yang masih belum dimilki oleh remaja dengan usia dini.

Adapun permasalahan yang sering muncul dalam pernikahan dini adalah perselisihan pendapat dan keinginan, perselisihan ini kerap kali menimbulkan perceraian dan kekerasan dalam rumah tangga. Kekerasan dan perceraian ini tentunya dapat menimbulkan trauma bagi remaja yang menikah dini. Dalam sosialisasi ini juga diungkapkan beberapa resiko non klinis yang terjadi akibat pernikahan dini. Sebagaimana kita fahami bersama pernikahan dini kerap kali menimbulkan berbagai resiko negative baik secara medis maupun non medis ( non klinis) diantaranya adalah resiko psikologis yaitu trauma apabila terjadi kekerasan dalam rumah tangga dan perceraian.

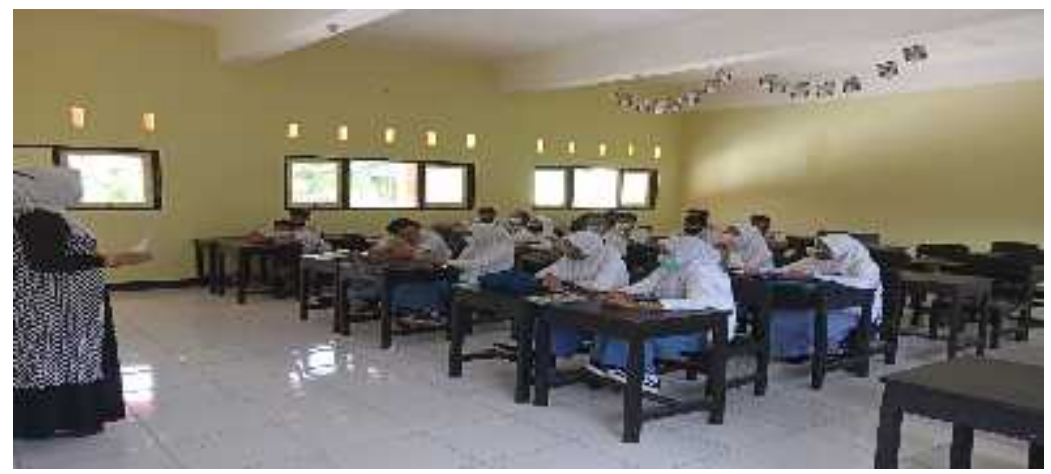

Gambar 1. Kegiatan Penyampaian Materi Pengabdian

Tim pengabdian masyarakat juga melakukan monitoring kegiatan dengan tujuan untuk mengetahui kelemahan atau kekurangan kegiatan pengabdian yang dilaksanakan. Setelah dilaksanakan kegiatan sosialisasi resiko non klinis pernikahan usia anak di SMAN 1 Gerung, tim pengabdian berupaya untuk melakukan evaluasi terhadap kegiatan pengabdian. Evaluasi ini bertujuan untuk mengetahui tingkat keberhasilan dari pelaksanaan kegiatan 
pengabdian masyarakat. Evaluasi terhadap proses kegiatan pengabdian untuk mengetahui tingkat pasrtisipasi, respon dan pemahaman terhadap materi sosialisasi yang disampaikan pemateri kepada peserta. Respon siswa terhadap kegiatan pengabdian ini terlihat antusias untuk bertanya.

Di akhir kegiatan peserta dan Tim melakukan refleksi hasil sosialisasi. Setelah semua kegiatan yang telah direncanakan terlaksana, ketua tim Pengabdian Masyarakat menutup program dan memberikan pesan kepada segenap peserta sosialisasi untuk menunda menikah pada usia anak, merencanakan masa depan, melanjutkan pendidikan untuk melanjutkan kehidupan yang lebih baik, merencanakan masa depan dengan lebih baik lagi serta selalu mengingat resiko-resiko menikah di usia anak. Diharapkan pada pengabdian masyarakat yang akan akan datang program ini dapat dilanjutkan lagi dengan bahasan yang lainnya. Tim pengabdian terus berupaya memberikan tindak lanjut dari kegiatan yang telah dilaksanakan dengan cara mengidentifikasi kekurangan kegiatan. Tim pengabdian akan melakukan tindak lanjut dengan melaksanakan kegiatan serupa pada masyarakat khususnya orang tua.

\section{Kesimpulan}

Kegiatan pengabdian pada masyarakat tentang resiko non klinis pernikahan usia anak bertempat di SMAN 1 Gerung, mendapat respon yang sangat baik, siswa merasa senang dan antusias dalam berdiskusi tentang resiko non klinis pernikahan usia anak, banyakanya pertanyaan membuat suasana kegiatan pengabdian semakin semarak. Dengan adanya kegiatan ini maka siswa mampu memahami apa saja resiko non klinis yan ditimbulkan dari pernikahan usia anak, bagaimana cara mencegah resiko-resiko buruk yang ditimbulkan oleh pernikahan usia anak, serta merencanakan kehidupan setelah SMA serta rencana untuk melanjutkan studi.

\section{Saran}

Berdasarkan kesimpulan di atas, tim pengabdian kepada masyarakat memberian saran sebagai berikut : Pertama, bagi sekolah Hendaknya program penyuluhan/ sosialisasi ini dapat terus berlanjut sehingga lebih banyak lagi sekolah yang dapat merasakan manfaatnya serta tingginya pernikahan usia anak dapat ditekan. Kedua bagi siswa, hendaknya hasil penyuluhan ini data dijadikan sebagai gambaran dan pertimbangan tentang bagaimana danpak negatif yang terjadi akibat pernikahan dini dan dapat lebh mempertimbangkan untuk melanjutkan studi. Karena salah satu pendukung terjadinya pernikahan dini adalah karena siswa tidak melanjutkan studi pada jenjang yang lebih tinggi.

\section{Daftar Pustaka}

BKKBN (2010). Pendewasaan Usia Perkawinan dan Hak-hak Reproduksi bagi Remaja Indonesia. D. R.d.P.H.-H. Reproduksi. Jakarta.

Endriani, A., Herna Astuti, F., Lukitasari, D., \& Rayani, D. (2020). Penyuluhan Pemahaman Layanan Informasi Tentang Studi Lanjut. Jurnal Pengabdian UNDIKMA, 1(2), 172176. doi:https://doi.org/10.33394/jpu.v1i2.3085

Mubasyaroh. 2016. "Analisis Faktor Penyebab Pernikahan Dini dan Dampaknya bagi Pelakunya". Journal Yudisia STAIN Kudus, Vol. 7, No.2, hlm. 285 - 411

Noor, Syahadatina.M.,dkk. (2018). "Klinik Dana” Sebagai Upaya Pencegahan Pernikahan Dini. CV Mine: Yogyakarta. 
Pramana, adi I Nyoman, Warjiman Warjiman, Luckyta Ibna Permana, 2018. "Faktor-Faktor Yang Mempengaruhi Pernikahan Usia Dini Pada Remaja Wanita" Journal Vol 3 No 2 (2018): JurnalKeperawatanSuakaInsan.

Suara NTB. 10 Februari 2020. Dampak Pandemi Pernikahan Dini Di Lobar Mencapai 480 Kasus.

Suarti, N., Astuti, F., Gunawan, I., Ahmad, H., \& Abdurrahman, A. (2020). Layanan Informasi Dalam Rangka Meminimalisir Kecemasan Akademik Siswa. Jurnal Pengabdian UNDIKMA, 1(2), 111-117. doi:https://doi.org/10.33394/jpu.v1i2.2836 